\title{
Spermatocyte-specific expression of constitutively active heat shock factor 1 induces HSP70i-resistant apoptosis in male germ cells
}

\author{
N Vydra ${ }^{1}$, E Malusecka ${ }^{1}$, M Jarzab ${ }^{1}$, K Lisowska ${ }^{1}$, \\ M Glowala-Kosinska ${ }^{1}$, K Benedyk ${ }^{1}$, P Widlak $^{2}$, Z Krawczyk $^{1}$ \\ and W Widlak*,1 \\ 1 Department of Tumor Biology, Maria Skłodowska-Curie Memorial Cancer \\ Center and Institute of Oncology, Gliwice Branch, 44-101 Gliwice, Poland \\ 2 Department of Experimental and Clinical Radiobiology, Maria Skłodowska- \\ Curie Memorial Cancer Center and Institute of Oncology, Gliwice Branch, \\ 44-101 Gliwice, Poland \\ * Corresponding author: W Widlak, Department of Tumor Biology, Maria \\ Sklodowska-Curie Memorial Cancer Center and Institute of Oncology, Gliwice \\ Branch, 15 Armii Krajowej, 44-101 Gliwice, Poland. Tel: + 483227896 69; \\ Fax: + 483223135 12; E-mail: wwidlak@io.gliwice.pl
}

Received 24.2.05; revised 30.6.05; accepted 13.7.05; published online 09.9.05 Edited by JL Tilly

\section{Abstract}

Spermatocytes, the most sensitive male germ cells to heatinduced apoptosis, do not respond to hyperthermia by inducing heat shock proteins (HSPs), including HSP70i, which has been previously shown to confer resistance to apoptosis in somatic cells. To dissect the mechanism of heat-induced apoptosis and to determine if we could protect spermatocytes by expressing HSP70i, we engineered transgenic mice that express in spermatocytes constitutively active heat shock transcription factor (HSF)1. Such HSF1 expression did not lead to transcription of inducible $\mathrm{Hsp} 70$ genes, but instead induced caspase-dependent apoptosis that mimicked heat shock-induced death of spermatogenic cells. Both mitochondria-dependent and death receptor-dependent pathways appear to be involved in such HSF1-induced apoptosis: the levels of Bcl-2 family proteins became increased, $\mathrm{p} 53$ protein accumulated and expression levels of caspase-8 and deathreceptor-interacting proteins (including Fas-associated death domain protein and TNF receptor associated death domain protein) became elevated. Surprisingly, the constitutive spermatocyte-specific expression of HSP70i in doubletransgenic males did not protect against such HSF1-induced apoptosis.

Cell Death and Differentiation (2006) 13, 212-222.

doi:10.1038/sj.cdd.4401758; published online 9 September 2005

Keywords: spermatogenesis; transgenic mice; heat shock proteins; heat shock factor; DNA microarrays

Abbreviations: CAD, caspase-activated DNase; CIDE, cell death-inducing DFF45-like effector; DFF, DNA fragmentation factor; FADD, Fas-associate- death domain protein; GAPDH, glyceraldehyde-3-phosphate dehydrogenase; HSE, heat shock element; HSF, heat shock transcription factor; HSP, heat shock protein family; ICAD, inhibitor of CAD; PERP, TP53 apoptosis effector; RIP, TNF receptor-interacting protein; TNFRSF, tumor necrosis factor receptor superfamily; TNFSF, tumor necrosis factors superfamily; TRAD̄D, T̄NF receptor associated death - domain protein; TRAF, TNF receptor ${ }^{-}$associated factor

\section{Introduction}

Spermatogenesis is a dynamic, highly ordered process encompassing germ cell proliferation, differentiation and cell death, by which mature haploid spermatozoa are produced (reviewed in Parvinen ${ }^{1}$ ). Primitive stem cells, called type A spermatogonia, proliferate and give rise to type B spermatogonia, which in turn differentiate into more specialized cells called spermatocytes. Spermatocytes undergo meiotic divisions and give rise to round spermatids. Subsequently, spermatids undergo a remarkable morphogenetic transformation to become spermatozoa.

Altered regulation of apoptosis during spermatogenesis is a medically important problem associated with male infertility. Apoptosis occurs during normal spermatogenesis, which is estimated to eliminate up to $75 \%$ of the potential number of mature spermatozoa. Furthermore, apoptotic death can be induced in these cells by alterations in hormonal support, exposure to toxic insults or increased scrotal temperature (reviewed in Print and Loveland ${ }^{2}$ and Hikim et al. ${ }^{3}$ ). In the majority of mammals male gonads are located outside the main body cavity, which provides a lower testicular temperature required for normal spermatogenesis and fertility. Consistently, suppression of spermatogenesis caused by testicular hyperthermia has been observed in certain disorders, such as cryptochidism and acute febrile diseases (reviewed in Kandeel and Swerdloff ${ }^{4}$ ). The incidence of germ cell apoptosis is markedly increased under conditions of testicular hyperthermia. Among the various germ cell types, primary spermatocytes are the most sensitive to local heat stress. $^{5-7}$

Somatic cells respond to thermal insult by inducing a set of heat shock proteins (HSPs) - a class of molecular chaperones involved in different cellular processes, whose main functions are to maintain the native folded states of cellular proteins and provide maintenance of cellular homeostasis and survival. Numerous studies demonstrate that cytoprotective functions of HSPs can be largely attributed to suppression of apoptosis (reviewed in Beere $^{8}$ and Sreedhar and Csermely ${ }^{9}$ ). In mammalian cells, there are five major families of HSPs, namely, the HSP100, HSP90, HSP70, HSP60 and small HSP (exemplified by HSP27/HSP25) (reviewed in Gething and Sambrook ${ }^{10}$ ). One characteristic feature of heat-shocked somatic cells is the abundant expression of inducible HSP70s (HSP70i) (reviewed in $\mathrm{Kregel}^{11}$ and Moseley ${ }^{12}$ ), which exert antiapoptotic effects that include: (i) inhibition of caspase-3 
activation by the apoptosome, ${ }^{13}$ and (ii) antagonizing the action of apoptosis-inducing factor (AIF), which is involved in caspase-independent apoptosis. ${ }^{14}$ In fact, different HSPs can interfere with both anti- and proapoptotic pathways (reviewed in Beere ${ }^{8}$ and Sreedhar and Csermely ${ }^{9}$ ). Numerous studies, however, have shown that overexpression of HSP70, in either transgenic mice or transfected cells, can protect different somatic cells from apoptotic death induced not only by the hyperthermia ${ }^{15}$ but also by other stimuli, including ischemia, ${ }^{16}$ nitric oxide, ${ }^{17}$ adriamycin, ${ }^{18}$ UV-B radiation ${ }^{19}$ or pathogenic viruses. $^{20}$

Two members of the HSP family are expressed normally under non-heat shock conditions specifically during spermatogenesis. Spermatocyte-specific HSP70, called HSP70.2 in mice and HST70 in rats, is expressed in pachytene spermatocytes during the meiotic phase. ${ }^{21-23}$ Another testisspecific HSP70, called HSC70t, is expressed in postmeiotic spermatids. ${ }^{24}$ In response to mild hyperthermia, HSP70i expression is induced in the somatic compartment of testes and possibly in the premeiotic germ cells, but is not induced in spermatocytes. ${ }^{25,26}$ It is known that testis-specific HSP70 proteins are crucial for development of male germ cells. ${ }^{27}$ However, the mechanism of their cytoprotective action is not known at present.

The transcription of genes encoding HSPs requires activated heat shock transcription factors (HSFs), which in vertebrates constitute a family with several members (HSF14). Vertebrate HSF1 is a functional homolog of HSF found in lower eukaryotes, and its activation is induced in vivo by different forms of cellular stress (e.g. heat shock). ${ }^{28,29}$ HSF2 is activated in a developmentally related manner, HSF4 is expressed in a tissue-specific manner, while heat-responsive HSF3 is expressed only in birds (reviewed in Pirkkala et al. ${ }^{30}$ and Voellmy ${ }^{31}$ ). More recently, HSF-similar factor HSFY, which is expressed predominantly in testis, has been discovered. ${ }^{32,33}$ Under physiological conditions HSF1 exists as an inactive monomer, while trimerization of HSF1 takes place in response to cellular stress and the trimer binds cisacting DNA sequences termed heat shock elements (HSEs) (reviewed in Fernandes et al. ${ }^{34}$ ). Activation-induced oligomerization of HSF1 is controlled by intra- and intermolecular hydrophobic interactions mediated by several conserved repeated motifs. ${ }^{35-37}$ Deletion of certain conserved regions of HSF1 leads to its constitutive trimerization and activation (reviewed in Voellmy ${ }^{38}$ ).

One would hypothetically expect that activation of HSF1 in spermatogenic cells should lead to the expression of inducible HSPs, which should render cytoprotective effects. However, it has been observed previously that neither heat-induced activation of $\mathrm{HSF}^{26}$ nor overexpression of active HSF1 results in expression of HSP70is in spermatogenic cells. ${ }^{39}$ In fact, though HSF1 acts as a cell-survival factor in premeiotic germ cells, ${ }^{26}$ expression of a constitutively active form of HSF1 in spermatocytes of transgenic mice induces massive degeneration of the seminiferous epithelium, which leads to male infertility. ${ }^{39,40}$ Here we have studied mechanisms such as tissue degeneration and demonstrate that both mitochondrial-dependent and death receptor-dependent apoptotic pathways are involved. We have also tested the hypothesis that such HSF1-induced apoptosis in spermatocytes might be a result of the lack of induction of the antiapoptotic protein HSP70i. Surprisingly however, we found that the constitutive spermatocyte-specific expression of HSP70i in double-transgenic males does not protect against such HSF1-induced apoptosis.

\section{Results}

\section{Expression of constitutively active HSF1 in cultured somatic cells results in the induction of HSP70 under non-heat shock conditions}

As we aimed to express a constitutively active form of HSF1 in mouse spermatocytes in vivo to presumably induce HSPs and mimic the conditions of heat shock, we first tested whether such expression in cultured mouse cells would induce HSP70 expression at physiological temperatures. For this purpose, we used a construct expressing hHSF1 $\Delta \mathrm{RD}$ under the control of the human $\beta$-actin gene promoter, corresponding to human HSF1 with a deletion in a heat-responsive regulatory domain (RD; residues 221-315), previously shown to produce a constitutively active form of this factor. ${ }^{39}$ Mouse melanoma B16 cells were transiently transfected with this construct, and the levels of HSF1, the HSE-binding activity and the levels of HSP70i were tested compared to nontransfected B16 cells, either before or after heat shock (Figure 1). As shown in Figure 1a, in addition to the longer endogenous $\mathrm{mHSF} 1$ form, the shorter hHSF1 $\mathrm{RRD}$ species was also detected in transfected cells grown at physiological temperature. The DNA-binding activity of HSF1 species was also examined in nuclear extracts before and after heat shock using the 'gel shift' assay with synthetic HSE duplex oligonucleotide. As shown in Figure 1b, nontransfected cell extracts exhibited an HSE-HSF1 complex only after heat shock, while transfected cell extracts formed a major HSE-hHSF1 $\triangle \mathrm{RD}$ complex both before and after heat shock. Finally, as shown in Figure 1c, HSP70i proteins were expressed only after heat shock in
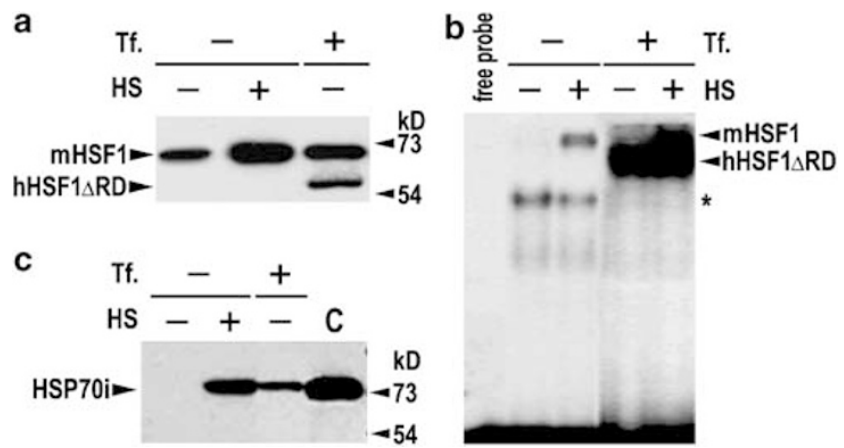

Figure $1 \mathrm{hHSF} 1 \triangle \mathrm{RD}$ expression in cultured somatic mouse cells induces HSP70i under physiological temperature. (a) - The Western-blot detection of endogenous mHSF1 and hHSF1 $1 \mathrm{RD}$ in B16 cells before or $48 \mathrm{~h}$ after transfection with the $h H S F 1 \triangle R D( \pm T f$.). Where indicated, cells were subjected to a heat shock (HS) for $1 \mathrm{~h}$ at $42.5^{\circ} \mathrm{C}$. (b) - Gel-shift analysis of HSE-binding activity of the indicated cell nuclear extracts (the minor higher mobility complex marked with asterisk corresponds to a Ku protein-containing complex). (c) - The Western-blot detection of inducible HSP70 before and after transfection of B16 cells with the $h H S F 1 \triangle R D$. Nontransfected cells were subjected to the heat shock and then recovered for $6 \mathrm{~h}$ at $37^{\circ} \mathrm{C}$. Lane $\mathrm{C}-$ Control lysates from V79 cells, which were transfected with constitutively active Hsp70i gene 
nontransfected cells, but were expressed in transfected cells grown at physiological temperature. We have thus demonstrated that expression of the hHSF1 $\triangle \mathrm{RD}$ in mouse somatic cells leads to induction of HSP70i at physiological temperature.

\section{Expression of constitutively active HSF1 in the testes of transgenic mice}

To specifically express $\mathrm{hHSF} 1 \Delta \mathrm{RD}$ in spermatogenic cells of transgenic mice, we chose to utilize a $3.5 \mathrm{~kb}$ segment of the spermatocyte-specific promoter of the rat Hst70/Hsp70.2 gene, which contains all the regulatory elements required for efficient, cell-type-specific expression of a transgene. ${ }^{41,42}$ The hHSF1 $\Delta$ RD gene under the control of the rat Hst70/Hsp70.2 gene promoter (Figure 2a) was used to generate three lines of transgenic mice and the line with highest testis-specific expression of the hHSF1 $\triangle \mathrm{RD}$ was chosen for further experiments. Though transgenic males proved to be infertile, transgenic females were fertile and did not reveal any specific phenotype. To determine whether the transgene was expressed in testes, RNA isolated from testes was analyzed by RT-PCR using a primer pair specific for hHSF1 $\Delta$ RD (the specificity was further confirmed by hybridization of RT-PCR products with a radioactive internal probe specific for $\mathrm{hHSF} 1 \Delta \mathrm{RD})$. As shown in Figure 2b, hHSF1 $1 \mathrm{RD}$ transcripts could be detected in testes of 15-day-old and older transgenic males (an RT-PCR product that was observed in samples

a
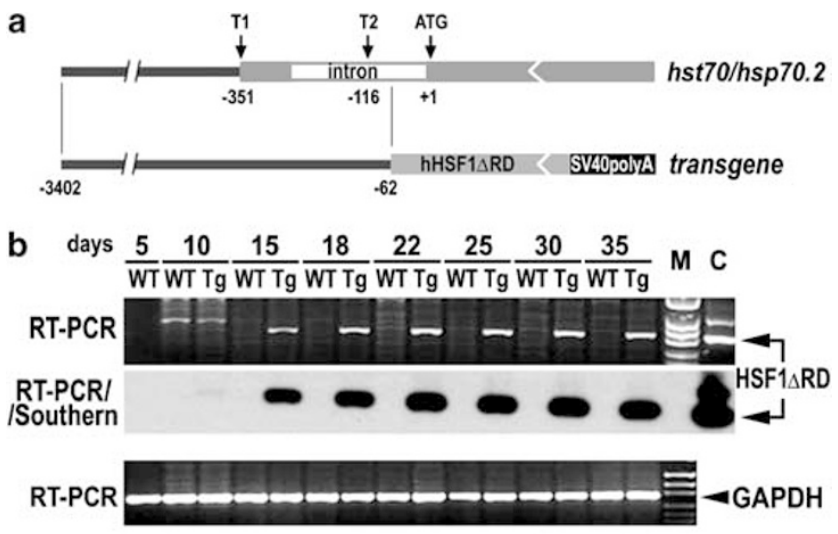

C

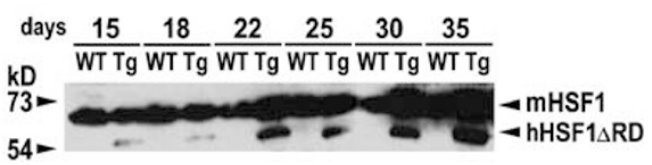

Figure 2 Expression of constitutively active HSF1 controlled by the Hst70/ Hsp70.2 gene promoter is developmentally regulated in the testes of transgenic mice. (a) - Schematic structures of the rat Hst70 gene and the pHST$\mathrm{hHSF} 1 \Delta \mathrm{RD}$ transgene. Shown are positions of the T1 and T2 transcription initiation sites and the translation start sites (ATG codon; + 1). (b) - Detection of transcripts of the hHSF1 $\Delta$ RD transgene in the testes of nontransgenic (WT) and transgenic (Tg) mice, at different time points after birth, by RT-PCR and Southern hybridization of amplified products with a transgene-specific probe. Lane $\mathrm{C}$ Control reaction with the pHST-hHSF1 $\triangle$ RD plasmid DNA as a template. The same RNA preparations were RT-PCR-analyzed with primers specific for the GAPDH housekeeping gene. (c) - The Western-blot detection of the endogenous mHSF1 and the hHSF1 $\triangle \mathrm{RD}$ in the testes of nontransgenic and transgenic mice at different time points after birth from 10-day-old mice was not specific for the transgene). As day 15th post partum corresponds to the onset of the pachytene stage of the first meiotic division, the observed timing of this expression pattern correlates well with the spermatocyte-specific promoter that we used. The appearance and accumulation of the $\mathrm{hHSF} 1 \Delta \mathrm{RD}$ protein in the testes of transgenic mice was then analyzed by Western blotting. As expected from the transcript levels, hHSF1 $\Delta$ RD protein could be detected in 15-day-old animals and further accumulation was observed in testes of 3-week-old and older transgenic males (Figure 2c). Although we have previously found that low amounts of the endogenous Hst70/Hsp70.2 gene transcripts could be detected also in brain, ${ }^{43}$ hHSF $1 \Delta \mathrm{RD}$ transcripts were not detected in any somatic tissues of our transgenic mice (data not shown). We conclude that we have established transgenic mice that exhibit testis-specific and developmentally specific expression of constitutively active HSF1.

\section{Expression of constitutively active HSF in mouse spermatocytes does not lead to the induction of HSP70i proteins}

We first performed RT-PCR assays to determine whether Hsp70i gene transcripts appeared in transgenic mice testes upon expression of constitutively active HSF1. The primer pair utilized was complementary to both mouse Hsp70 inducible genes, Hsp70.1 and Hsp70.3 (the specificity was further verified by hybridization of the amplified fragment with a radioactive internal probe specific for both Hsp70is). At the same time, two control RT-PCR reactions were performed: to detect the Hst70/Hsp70.2 transcripts (a marker of spermatocytes) and glyceraldehyde-3-phosphate dehydrogenase $(G A P D H)$ transcripts (a control for the quantity and quality of

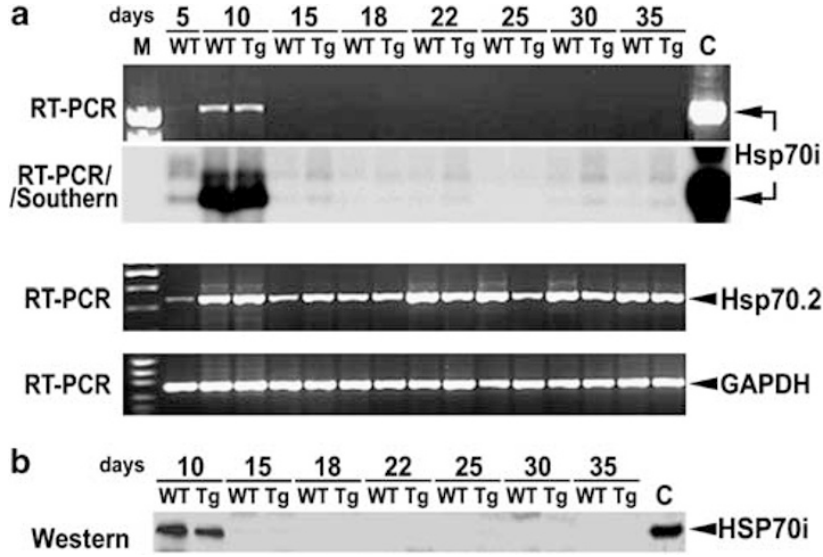

Figure 3 The expression of constitutively active HSF1 does not induce Hsp70 genes in spermatogenic cells of transgenic mice. (a) - Detection of transcripts of both Hsp70.1 and Hsp70.3 genes in the testes of nontransgenic (WT) and transgenic $(\mathrm{Tg})$ mice, at different time points after birth, by RT-PCR and Southern hybridization of amplified products with a gene-specific probe. Lane $\mathrm{C}-$ Control reaction with pHSP7OM plasmid DNA as a template. The same RNA preparations were RT-PCR-analyzed with primers specific for the testis-specific Hsp70.2 and the GAPDH housekeeping genes. (b) - Western-blot detection of inducible HSP70 proteins in the testes of nontransgenic and transgenic mice, at different time points after birth. Lane $\mathrm{C}$ - control lysates from V79 cells constitutively expressing HSP70i 
RNA). As shown in Figure 3a, in developing testes transcripts of inducible Hsp70i genes could be detected only at day 10 after birth, in either nontransgenic or transgenic males. The constitutive Hst70/Hsp70.2 transcripts were present in testes of mice at all time points investigated, although 5 days after birth the level of transcripts was significantly lower than in that in the testes of older mice (transcripts present in the testes of 5- and 10-day-old males originate from the T2 transcription start site and are not translated ${ }^{44}$ ). As expected from the RNA transcript data, the HSP70i proteins could only be detected in the testes of 10-day-old males. Although low amounts of HSP70i could also be detected in the testes of some 15-dayold animals, no protein was found in older animals (Figure $3 b$ ). To summarize, although $\mathrm{hHSF} 1 \Delta \mathrm{RD}$ is transcriptionally competent and activates Hsp70i genes in somatic cells, and is expressed in our transgenic animals in the testes, it is unable to activate the endogenous Hsp70i genes in spermatocytes. These results demonstrate that the endogenous Hsp70i genes are repressed in meiotic and postmeiotic spermatogenic cells, possibly at the level of chromatin structure, and cannot be activated by HSF1.

\section{The spermatocyte-specific expression of the constitutively active HSF1 leads to activation of caspase- 3 and apoptosis of spermatogenic cells}

We have previously observed that spermatocyte-specific expression of the hHSF $1 \Delta \mathrm{RD}$ resulted in infertility of transgenic males that was caused by a massive degeneration of the seminiferous epithelium in adult animals. ${ }^{40}$ To determine the mechanism of such degeneration, we first performed immunohistochemical analysis on testes from 15-, 18-, 22-day-old as well as older mice to detect apoptosisspecific DNA breaks (using the TUNEL assay) and active caspase-3 (Figure 4). Only few individual cells containing either DNA breaks or active caspase-3 could be detected near
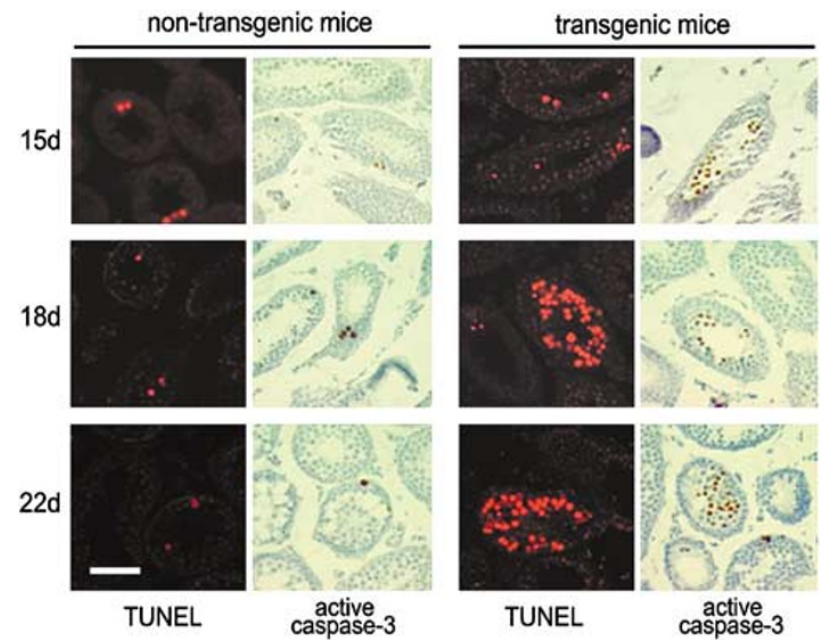

Figure 4 The expression of constitutively active HSF1 in spermatogenic cells results in DNA fragmentation and caspase-3 activation. Detection of DNA breaks (by TUNEL assay) and active caspase-3 (by immunohistochemistry) in seminiferous tubules of wild-type and pHST-hHSF1 $\triangle \mathrm{RD}$ transgenic mice, 15, 18 or 22 days after birth. The scale bar represents $100 \mu \mathrm{m}$ the basement membrane of seminiferous tubules of nontransgenic males, which reflects apoptosis of premeiotic spermatogenic cells. ${ }^{45}$ In marked contrast to wild-type males, clusters of cells containing active caspase- 3 could be detected centrally within the seminiferous tubules of transgenic males (15-day-old and older), presumably corresponding to the hHSF1 $\triangle \mathrm{RD}$-expressing spermatocytes. As development proceeded, clusters of cells with numerous DNA breaks were detected in the lumen of seminiferous tubules of transgenic animals (starting from 18-day-old) that corresponded to a progression of apoptosis. Generally, in tubules where cells with DNA breaks were visible, active caspase-3 was also stained. However, there were usually more TUNEL-positive cells as compared to caspase-positive cells in a particular tubule. Most surprisingly, only few spermatogenic cells were found to be a double-positive (1-3 cells per tubule section; Supplementary Figure $\mathrm{S} 1$ available at the Cell Death and Differentiation website). The data suggest that the amount of active caspase-3 diminishes at the time when DNA breaks accumulate and can be detected. However, we cannot exclude the possibility that some spermatogenic cells die by a caspase-independent apoptosis.

\section{The spermatocyte-specific expression of the constitutively active HSF1 leads to increased levels of proapoptotic proteins associated with both mitochondrial and death-receptor pathways}

To further characterize apoptotic processes in the testes of these transgenic mice, we assayed for the presence of apoptosis-related proteins in testicular cell lysates by Western blotting using a panel of antibodies. Animals, 15-day-old, when hHSF1 $\triangle$ RD becomes first expressed, and 22-day-old animals, where apoptosis of spermatogenic cells is in progress, were selected for this analysis (Figure 5). Proteins associated with the mitochondrial pathway of apoptosis were
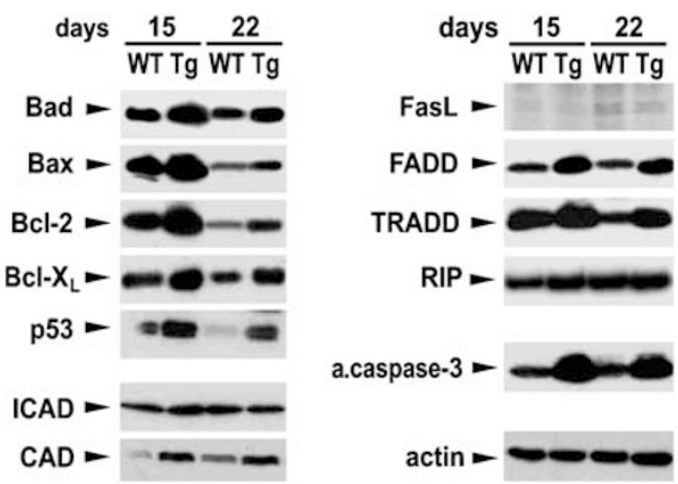

Figure 5 Expression of constitutively active HSF1 in spermatogenic cells modulates the levels of different proapoptotic and antiapoptotic proteins. The levels of apoptosis-related proteins were analyzed in testicular extracts of nontransgenic (WT) and transgenic (Tg) mice, either 15 or 22 days after birth, by Western blotting. Representative results of experiments performed separately on samples from three different animals for each of the experimental points are shown. Densitometry quantification of Western blot data for each of the analyzed animals was performed and the resulting quantitative data are available as a Supplementary Table 1 
first analyzed (Figure 5, left panel). We observed that the levels of proapoptotic (Bad and Bax) and antiapoptotic (Bcl-2 and $\mathrm{Bcl}-\mathrm{X}_{\mathrm{L}}$ ) Bcl-2 family proteins were higher in the testes of 15- and 22-day-old transgenic animals as compared to nontransgenic controls. Importantly, the levels of examined $\mathrm{Bcl}-2$ family proteins were higher in the testes of 15-day-old animal, nontransgenic controls as compared to 22-day-old nontransgenic animals as well. Such increased levels of Bcl-2 protein family apparently reflect the 'physiological' early apoptotic wave in premeiotic germ cells that is essential for normal spermatogenesis which peaks at approximately 2 weeks after birth. ${ }^{46,47}$ In addition, markedly elevated levels of p53 protein occurred in the testes of transgenic animals (either 15- or 22-day-old) as compared to nontransgenic controls. The Fas ligand and three adapter proteins interacting with death receptors (TNF receptor associated death domain protein (TRADD), Fas-ässociated death domain protein (FADD) and TNF receptor-interacting protein (RIP)) involved in the activation of initiator caspase-8 were also analyzed (Figure 5, right panel). Although the levels of Fas ligand and RIP remained unchanged, the levels of FADD and TRADD proteins increased in the testes of transgenic males, the former one also early after activation of the transgene (15day-old mice). The differences in the levels of mitochondriarelated and death receptor-related apoptotic proteins between transgenic and nontransgenic animals were reproducibly significant (Supplementary Table S1 available at the Cell Death and Differentiation website). In agreement with immunohistochemical data (Figure 4), the level of active caspase-3 was elevated markedly in the testes of transgenic animals. We also examined the levels of subunits associated with a major apoptotic DNase - DNA fragmentation factor (DFF). The level of its inhibitory subunit (inhibitor of CAD (ICAD)/DFF45), which is cleaved by caspase-3 during apoptosis, was not reduced in the testes of 22-day-old transgenic animals. This unexpected observation is presumably due to the presence of excess intact ICAD from nonapoptotic cells in the material tested. Interestingly, the level of the catalytic subunit of the nuclease (caspase-activated DNase (CAD)/DFF40) was elevated in the testes of transgenic males. Taken together, the above results demonstrate that the levels of several proapoptotic proteins associated with both mitochondrial 'intrinsic' and death-receptor 'extrinsic' pathways become increased in spermatogenic cells expressing hHSF1 $\Delta$ RD.

In addition, we have accessed the activity of caspase-3, caspase- 8 and caspase- 9 in extracts from testicular cells using specific colorimetric substrates. The activities of each of three caspases were measured in extracts from 15-day-old transgenic animals and compared to such activities in wildtype males. The in vitro activities of all three caspases were slightly higher in extracts from the testes of transgenic animals: 1.5- 1.3- and 1.1-fold increase for caspase-3, caspase- 8 and caspase- 9 , respectively. Although we have observed only moderate increases in the caspase activities in transgenic animals, apparently because of heterogeneity of analyzed tissue, the data support the notion that both 'intrinsic' and 'extrinsic' pathways can be involved in the HSF1-induced apoptosis.

\section{Expression of constitutively active HSF1 modestly affects gene expression profiles in the testes of transgenic males}

We have further studied the effects of the hHSF1 $\triangle R D$ expression by an analysis of global gene expression profiles in the testes of 15-day-old transgenic animals. Expression profiles from three transgenic and four nontransgenic animals were compared using oligonucleotide microarrays. We selected 713 genes that showed differential expression between both groups and properly subdivided the analyzed tissues into wild type or transgenic (Figure 6a). However, the change between the expression profiles of nontransgenic and transgenic animals was not large enough to pass the multiplecomparison $P$-value threshold. The gene ontology classification performed on 713 selected genes revealed that 'DNA binding' and 'DNA-dependent regulation of transcription' classes are the most numerous (51 and 34 genes, respectively; overlap $P$-value $<0.05)$. Subsequently, we have assessed which of 713 'differentiating' genes were related to either chaperones/cellular stress or apoptosis. We have found 11 chaperone-related transcripts in the set of such differentiators. The most prominent difference was visible for

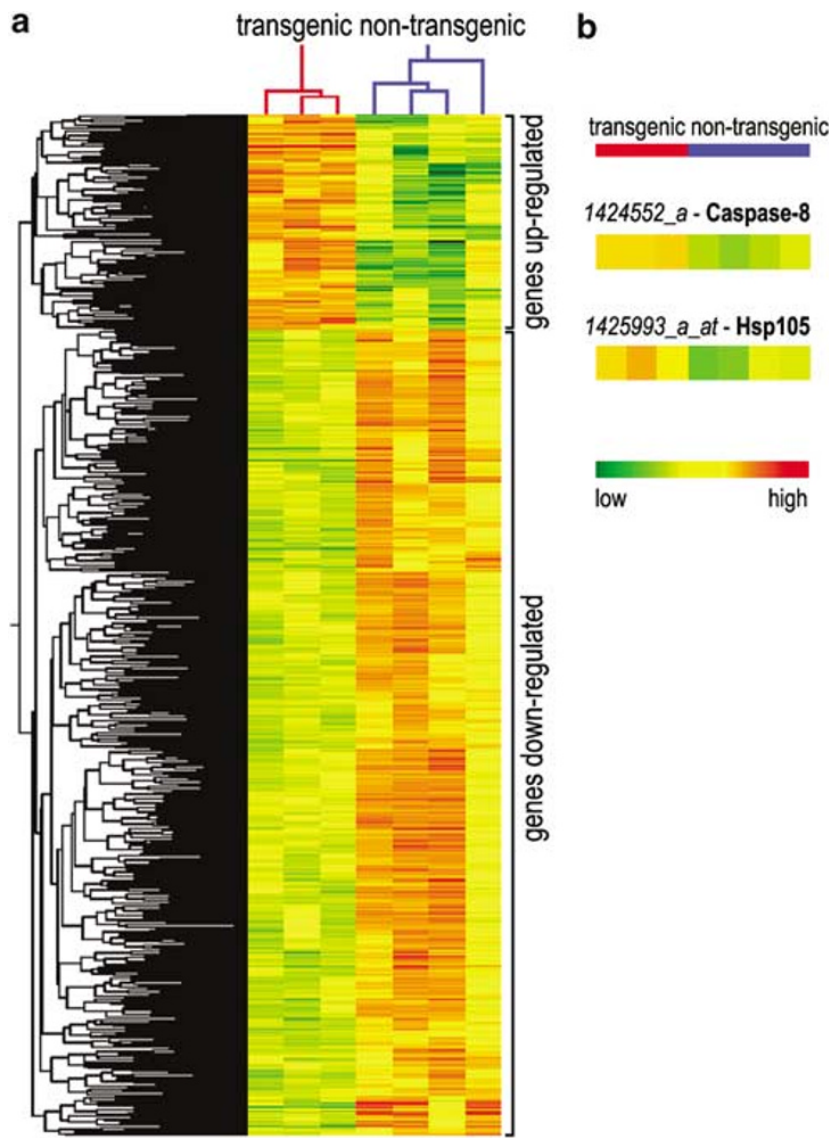

Figure 6 Expression of constitutively active HSF1 in spermatogenic cells results in characteristic changes in gene expression profiles in the testes of 15day-old transgenic mice. The hierarchical clustering of 713 of the most differentially expressed genes (Welch $t$-test noncorrected $P<0.05$ ) between transgenic and nontransgenic animals - (a). Expression levels of caspase-8 and HSP105 in the testes of three transgenic and four nontransgenic - (b) 
Hsp105 gene (about a 50\% increase in the absolute value, Figure $6 \mathrm{~b}$ ). The levels of transcripts of other chaperones ( $H s p 40$ and $H s p 60)$ also slightly increased in the testes of transgenic animals. A total of 10 genes related to apoptosis (GO term 6915 and 6916) were found inside the set of differentiating genes. The most marked change was noted for caspase- 8 gene (about a $50 \%$ increase in the absolute value in transgenic males; Figure 6b). In addition, expression of several additional apoptosis-related genes represented on DNA microarray was slightly up- or downregulated. The mouse genome database search using the TRANSFAC software (http://dbtss.hgc.jp) revealed 190 genes or hypothetical genes that contained HSE consensus sites in their promoter regions, which were represented in the used DNA microarray. However, only 12 of such HSE-containing genes were found inside the set of 713 differentiating genes, including Hsp105. Five HSE-containing genes were apoptosis-related: ankyrin3 (Ank3), Bcl2-antagonist/killer1 (Bak1), Casp8 and FADD-like apoptosis regulator or FLIP (Cflar), serine/threonine kinase 3 or STE20-like kinase (Stk3) and phosphatidylserine receptor (Ptdsr), but small differences in their expression levels between wild-type and transgenic males were statistically insignificant.

The gene expression profiles were also analyzed in the testes of either 22-day-old nontransgenic or transgenic mice. In this case, we observed a striking decrease of expression of the genes involved in spermatogenesis (63 genes - $49 \%$ ) and molecular chaperones (46 genes $-40 \%$ ) in the testes of transgenic animals in comparison to wild-type animals. Simultaneously, the pairwise analysis reveled numerous apoptosis-related genes that were differentially expressed in normal and transgenic animals. Among genes that were moderately or significantly upregulated (Tg/WT corrected signal log ratios $>0.4$ ) in the testes of transgenic animals, we have found proapoptotic Bcl-2 family proteins (Bax, Bid, Bok and Bcl-2 like protein 11), caspases (-6, -7, -8, -9), p53 and its proapoptotic target (TP53 apoptosis effector (PERP)), members of tumor necrosis factor receptor superfamily (TNFRSF$1,-6,-9,-12,-21)$, tumor necrosis factors (TNFSF-7, -8, -9, $-11,-12)$, the tumor necrosis factor receptor-interacting proteins (TNF receptor associated factor (TRAF)-4, -5, -6, FADD, CRADD) and other effectors of apoptosis (e.g. cell death-inducing DFF45-like effector (CIDE)-A and -B). These data are consistent with the results of Western analyses of apoptotic proteins' levels and further confirm that different apoptotic pathways are involved in degeneration of spermatogenic cells expressing HSF1. However, because apoptosis was essentially advanced in the testes of 22-day-old animals, such massive changes reflect ongoing processes, but do not disclose the initiating events occurring earlier in development.

\section{The constitutive spermatocyte-specific expression of HSP70i in double-transgenic males does not protect against HSF1-induced apoptosis}

The expression of constitutively active HSF1 induces apoptosis in spermatogenic cells that, in contrast to somatic cells, remarkably do not express inducible $H s p 70$ genes. This leaves open the unanswered question of whether HSP70i proteins might have cytoprotective antiapoptotic effects in spermatocytes. To answer this question, we generated transgenic mice that contained the heat-inducible Hsp70.1 gene under control of the spermatocyte-specific promoter of the Hst70 gene (pHST-HSP70i). As expected, the transgene was specifically expressed in spermatocytes in a characteristic developmentally regulated manner (data not shown). The $\mathrm{HSP}^{+}{ }^{+}$transgenic males are fertile; seminiferous tubules in their testes have normal morphology, with no signs of degeneration (Figure 7). We mated the $\mathrm{HSP}^{+} 0^{+}$transgenic males with $\mathrm{HSF}^{+}{ }^{+}$transgenic females to generate doubletransgenic animals that would express both HSP70i and constitutively active HSF1 in spermatocytes. As shown in Figure 7 (left panel), severe degeneration of the seminiferous epithelium still occurs in adult double-transgenic males, where majority of seminiferous tubules contained only premeiotic spermatogonia. The morphology of testes of $\mathrm{HSF} 1^{+}$transgenic and double-transgenic males was indistinguishable. Similar to $\mathrm{HSF}_{1}{ }^{+}$transgenic males, clusters of cells with

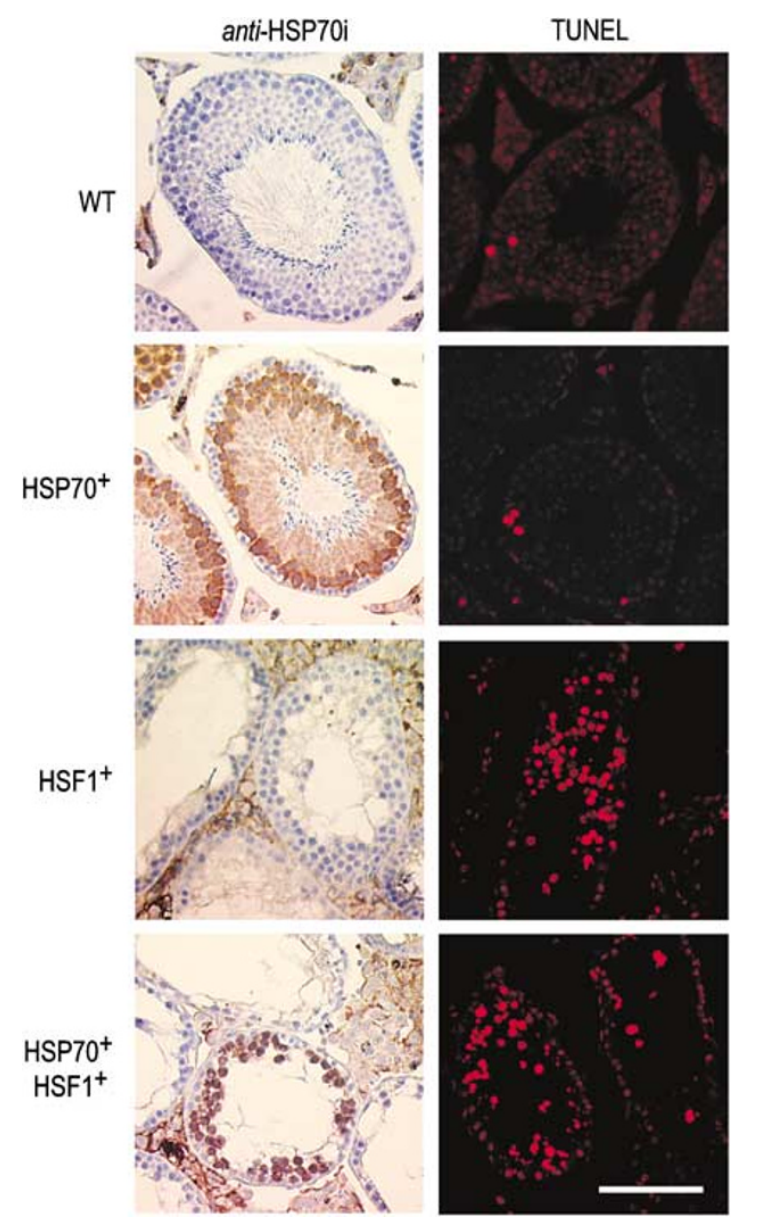

Figure 7 Expression of HSP70i does not prevent the HSF1-induced apoptosis in male germ cells. Detection of HSP70i (by immunohistochemistry) and DNA breaks (by TUNEL assay) in seminiferous tubules of nontransgenic (WT), pHSTHSP70i transgenic $\left(\mathrm{HSP}^{+}{ }^{+}\right.$), pHST-hHSF1 $\triangle \mathrm{RD}$ transgenic $\left(\mathrm{HSF}^{{ }^{+}}{ }^{+}\right.$) and double-transgenic males, 6 -week-old. Slides were counterstained with hematoxylin to visualize the morphology. The scale bar represents $100 \mu \mathrm{m}$. Nonspecific staining of interstitial/Leydig cells is visible between seminiferous tubules 
numerous DNA breaks (TUNEL positive) were detected in the lumen of the seminiferous tubules of double-transgenic animals (Figure 7, right panel). Thus, we conclude that the presence of the heat-inducible HSP70i does not protect spermatogenic cells from the apoptosis induced by active HSF1.

\section{Discussion}

Spontaneous male germ cell death during normal development most likely occurs in order to limit the number of germ cells, to match the supportive capacity of Sertoli cells, and this initial wave of apoptosis is characteristic of the premeiotic stage of spermatogenesis. Moreover, apoptosis serves as a checkpoint to eliminate spermatogenic cells with altered genomes, such as those harboring DNA damage. However, the mechanisms by which proapoptotic stimuli activate germ cell apoptosis are not well understood. The Bcl-2 family proteins, which are involved in regulation of the mitochondrialdependent apoptotic pathway, are indispensable for the development of male germ cells and genetically modified animals, with loss- or gain-of-function mutations in genes that encode either anti- or proapoptotic $\mathrm{Bcl}-2$ proteins, exhibit impaired spermatogenesis and infertility (reviewed in Print and Loveland ${ }^{2}$ ). It has been postulated that Fas-mediated pathways are involved in germ cell apoptosis induced by a paracrine mechanism by Sertoli cells, especially after certain types of testicular injury (e.g. ischemia). ${ }^{48,49}$ Apoptotic processes involved in testicular development could also be regulated by another death factor - TNF $\alpha$, which is expressed in spermatocytes and spermatides (reviewed in Lysiak ${ }^{50}$ ). In contrast, it has been reported that hyperthermia-induced apoptosis of spermatogenic cells remains unaffected in mice lacking either Fas receptor (TNFRSF-6) or Fas ligand (TNFSF-6), indicating that a Fas-dependent mechanism is dispensable in this process (reviewed in Hikim et al. ${ }^{3}$ ). In our experimental model, apoptosis was induced in meiotic spermatogenic cells by expression of the constitutively active HSF1, which plausibly mimics heat-shock conditions. Consistent with earlier observations, the level of Fas ligand remained unchanged in the testes of HSF1-expressing animals. However, we observed elevated expression of caspase-8 and death-receptor adapter proteins in such transgenic males early after expression of the transgene. This suggests that both 'intrinsic' mitochondrial-dependent and 'extrinsic' death receptor/caspase-8-dependent pathways are involved in the HSF1-dependent induction of apoptosis in male germ cells.

As the most obvious, we have presumed that induction of apoptosis in spermatogenic cells expressing HSF1 $1 \mathrm{RD}$ is related to the transcriptional activity of HSF1. The HSF1 trimer binds to conserved HSE that consists of the 5-bp module [nGAAn] arranged as an array of inverted triple repeats, ${ }^{51}$ and the mammalian genome would contain several thousand copies of such consensus sites (5'-nGAAnnTTCnnGAAn-3'). In fact, computational genomic studies have revealed that 182 promoters of human genes contain likely HSEs and binding of HSF1 to 94 of them has been confirmed by chromatin immunoprecipitation experiments in somatic cells. ${ }^{52}$ More- over, it is well documented that, besides the regulation of $H s p$ genes, HSF1 can activate several other genes. ${ }^{53,54}$ In addition, HSF1 can also act as a negative regulator of certain non-heat shock genes, including interleukin (IL)-1 $\beta$ or TNF $\alpha .{ }^{55-57}$ Myers et al. ${ }^{52}$ had shown that in heat-shocked somatic cells at least two promoters of putative apoptosisrelated genes - TNFRSF member 21 and death domain DNAbinding protein 2 - bound to and were activated by HSF1. Here we have aimed to disclose apoptosis-related genes that are regulated by HSF1 in spermatogenic cells.

In order to identify genes involved in the process of degeneration of spermatocytes, three groups of genes were selected for detailed analyses: genes specifically expressed in spermatocytes, genes encoding proteins involved in apoptosis and genes whose expression is regulated by HSF1. Expression of the most spermatocyte-specific genes was not changed significantly in testes of 15-day-old transgenic animals, when expression of the transgene and degenerative changes become detectable. Analysis of the expression of apoptosis-related genes revealed that only a gene encoding for caspase-8 happened to be significantly upregulated in the testes of transgenic mice early after expression of constitutively active HSF1. In fact, the promoter of the caspase- 8 gene does not contain a HSE consensus site, thus HSF1 may not be directly responsible for its activation. Computational mouse genome analyses revealed five genes that are apoptosis-related and contain HSE in their promoters, but none of them was significantly up- or downregulated early after expression of HSF1. Among other genes, which contain HSE in their regulatory regions, only expression of the heat shock gene Hsp 105 was significantly upregulated in the testes of 15-day-old transgenic mice. HSP105 is constitutively expressed in most mammalian tissues; yet, the role of this protein in cellular processes has not been unambiguously defined. In the rat testes, HSP105 was found to form complexes with p53 in the cytoplasm of germ cells at scrotal temperatures, while under heat shock conditions inducing spermatocyte apoptosis it dissociated from such complexes. ${ }^{58}$ Germ cell death appeared to include p53dependent mechanisms and p53 is essential to maintain cellular integrity and appropriate number of germ cells during spermatogenesis. ${ }^{59}$ Thus, one might speculate that the increased expression of HSP105 can affect the functional status of p53 in testes of transgenic males and induce spermatocyte apoptosis.

In fact, the gene expression profiling of the hHSF1 $\Delta$ RDexpressing animals did not reveal any simple clue as to the mechanism that induces degeneration of the seminiferous epithelium of transgenic males. The change in expression profile in $\mathrm{hHSF} 1 \triangle \mathrm{RD}$ mice is rather modest; this was probably because of a complex composition of the analyzed tissue and may not be resolved without isolation of specific populations of testicular cells. In addition, as an alternative explanation, one could also propose that active HSF1 interacts with other cellular protein(s), modifying its activity and inducing apoptosis, which is not clear at the moment. However, further deletion of the DNA-binding domain of the hHSF1 $\triangle R D$ (residues 17-90, data not shown) totally abolished the ability of a corresponding transgene to induce apoptosis, indicating that transcriptional activity of HSF1 is indispensable for its 
proapoptotic functions in spermatocytes. Undoubtedly, the identification of apoptotic genes regulated by HSF1, either directly or indirectly, needs further analyses.

The apoptosis induced by constitutively active HSF1 was not observed in somatic tissues and appears to be restricted to spermatogenic cells. ${ }^{39}$ Such tissue specificity could be explained if we assume that HSF1 regulates a set of genes (or modulates the functions of proteins), which are strictly related to processes specific for spermatogenic cells. Alternatively, one might postulate that the proapoptotic effects of HSF1 are compromised in somatic cells by the antiapoptotic activity of HSP70i, which are not expressed in spermatogenic cells. However, this latter explanation seems improbable in a light of the fact that spermatocyte-specific expression of HSP70i does not protect $\mathrm{HSF}^{+} / \mathrm{HSP}^{+} 0^{+}$double-transgenic males from HSF1-induced apoptosis in germ cells.

\section{Materials and Methods}

\section{DNA constructs and generation of transgenic mice}

The hHSF1 $\triangle$ RD construct encoding an active form of human HSF1 (with a deletion of amino acids 221-315), driven by the human $\beta$-actin promoter, was kindly provided by $\mathrm{Dr}$. A Nakai. ${ }^{39}$ The $\beta$-actin promoter was replaced by the HindIII(-3402)-Drall(-62) fragment of the rat Hst70 gene promoter (GenBank accession no. X15705; coordinates of restriction sites refer to $A(+1)$ in the ATG codon), to obtain the pHST-hHSF1 $\triangle R D$ plasmid used for generation of transgenic mice as described earlier (Figure 2). ${ }^{40}$ Breeding lines of transgenic mice were maintained by crosses to FVB/N males. The pHST-HSP70i plasmid was constructed by inserting the HindIII(-897)-BamHI(-120) fragment of the rat $\mathrm{Hst70}$ gene in front of a coding sequence spanning positions from 619 to 2762 of the mouse Hsp70.1 gene (GenBank accession no. M35021) ${ }^{60}$ cloned in the plasmid pCDNA3, which contains the bovine growth hormone polyadenylation sequence. To generate transgenic mice, the HindllI-Pvull fragment cut from the pHST-HSP70i plasmid was microinjected into the pronuclei of zygotes from FVB/N females by standard procedures. All animal experiments were approved by the Committee of Ethics and Animal Experimentation.

\section{Cell lines and transfection}

Mouse melanoma B16(F10) and Chinese hamster fibroblasts V79 cells were routinely cultured in RPMI 1640 medium (Sigma) supplemented with $10 \%(\mathrm{v} / \mathrm{v})$ heat-inactivated fetal bovine serum (FBS) (ICN Pharmaceuticals, Inc.). and $40 \mu \mathrm{g} / \mathrm{ml}$ gentamicin sulfate (Sigma). Cells were grown at $37^{\circ} \mathrm{C}$ and $5 \% \mathrm{CO}_{2}$ until $80-95 \%$ confluence. Cells were passaged every $2-3$ days and harvested with $0.05 \%$ trypsin (Gibco BRL). The transient transfections were carried out using Lipofectamine ${ }^{\mathrm{TM}} 2000$ (Invitrogen) according to the manufacturer's protocol. At 1 day before transfection, cells were seeded on $60-\mathrm{mm}$ plates at a concentration of $7.5 \times 10^{5} / \mathrm{ml}$ and incubated until $60-70 \%$ confluence. For each transfection, $8 \mu \mathrm{g}$ of DNA was diluted into $500 \mu \mathrm{l}$ of Opti-MEM (Gibco BRL) and added to the liposome dilution. The liposome dilution was prepared by adding $20 \mu \mathrm{l}$ of liposomes $(1 \mathrm{mg} / \mathrm{ml})$ into $500 \mu$ l Opti-MEM, followed by incubation at room temperature for $5 \mathrm{~min}$. The DNA-liposome mixtures were incubated for $30 \mathrm{~min}$ to allow DNA-liposome complexes to form. While complexes were forming, the cells were washed twice with serum-free medium and serumfree medium was added. DNA-liposome complexes were dropped on plates with cells, coincubated for $3 \mathrm{~h}$, then DNA-liposome complexes were removed by a change of serum-free medium into medium supplemented with serum and cells were incubated for an additional $48 \mathrm{~h}$ (the transfection with empty vector did not induce HSP70i synthesis; not shown). Heat shock was performed by placement of the $60-\mathrm{mm}$ plates of logarithmically growing cells in an incubator at a temperature $42.5^{\circ} \mathrm{C}$ for $1 \mathrm{~h}$. Cells were then allowed to recover at $37^{\circ} \mathrm{C}$ for $6 \mathrm{~h}$ or lyzed immediately after heat shock.

\section{Gel mobility shift assay}

Nuclear extracts were prepared as described by Suzuki et al. ${ }^{61}$ Briefly, nuclei isolated from cells lyzed by Nonidet-P40 were extracted with buffer consisting of $0.35 \mathrm{M} \mathrm{NaCl}, 5 \mathrm{mM}$ EDTA, $1 \mathrm{mM}$ DTT, $10 \mathrm{mM}$ Hepes, pH 7.9 and $0.2 \mathrm{mM}$ PMSF by incubation on ice for $20 \mathrm{~min}$. DNA binding was determined after incubation of $5 \mu \mathrm{g}$ of extracted nuclear proteins with a double-stranded oligonucleotide containing the HSE sequence (5'-GCT TCT AGA AGC TTC CTA GAA GCT TCT AGA A-3') labeled with ${ }^{32} \mathrm{P}$. Binding buffer contained $20 \mathrm{mM}$ Tris- $\mathrm{HCl}$, pH 7.6, $5 \mathrm{mM} \mathrm{MgCl}_{2}, 1 \mathrm{mM}$ DTT, $5 \%$ glycerol, $1 \mathrm{mM}$ EDTA, $0.2 \mathrm{M} \mathrm{NaCl}, 2 \mu \mathrm{g}$ poly(dl-dC). Samples were electrophoresed on $6 \%$ polyacrylamide gels in $0.5 \times$ TBE. Gels were dried and exposed to an X-ray film.

\section{RNA isolation, RT-PCR and hybridization}

Total RNA was extracted using the guanidine isothiocyanate method. ${ }^{62}$ RNA samples were purified from DNA contamination by digestion with DNasel. ${ }^{43}$ The RT-PCR assays were performed essentially according to Singer-Sam et al. ${ }^{63}$ At the reverse transcription step, the reaction mixture (final volume $30 \mu \mathrm{l}$ ) contained: $1.5 \mathrm{mM} \mathrm{MgCl}, 0.2 \mathrm{mM}$ each dNTPs, $0.4 \mu \mathrm{M}$ primers (each), RNA $(0.5-3 \mu \mathrm{g})$, MMLV reverse transcriptase (30 U, Gibco BRL), ribonuclease inhibitor (24U, Fermentas) and Taq polymerase (1.2 $\mathrm{U}$, Fermentas). Samples were incubated in a thermal cycler for $10 \mathrm{~min}$ at $50^{\circ} \mathrm{C}$. The reverse transcriptase was inactivated by heating for $5 \mathrm{~min}$ at $94^{\circ} \mathrm{C}$ and the next 35 cycles of the PCR were performed under optimal conditions for the primer pairs used. RT-PCR products were analyzed on $1-2 \%$ agarose gels containing ethidium bromide and blotted to Hybond $\mathrm{N}+$ membranes (Amersham Pharmacia Biotech). PCR primers used were: HSF1 forward - 5'-CCA GCA ACA GAA AGT CGT CA-3', reverse - 5'-GAG CTC ATT CTT GTC CAG CG-3'; Hsp70i forward - 5' -CCA TCC AGA GAC AAG CGA AG-3', reverse - 5' CGT TTA GAC CGC CGA TCA CA-3'; Hsp70.2 forward - 5'-AGG ACC CAC CAT TGA AGG AAG TG-3', reverse - 5'-GTA TGT ACG TGG AGA TTT GCC TTG A-3'; GAPDH forward - 5'-CGT CTT CAC CAC CAT GGA GA-3' ${ }^{\prime}$, reverse - 5'-CGG CCA TCA CGC CAC AGT TT-3'. Hybridization was carried out overnight with a ${ }^{32} \mathrm{P}$-labeled internal oligonucleotide probe in hybridization solution containing $5 \times$ SSC, $5 \times$ Denhardt's reagent, $0.5 \% \mathrm{SDS}, 100 \mu \mathrm{g} / \mathrm{ml}$ salmon sperm DNA at $55-65^{\circ} \mathrm{C}$. Membranes were washed at room temperature in $2 \times \mathrm{SSC}, 0.1 \% \mathrm{SDS}$ for $5 \mathrm{~min}$, and then in $1 \times$ SSC, $0.1 \%$ SDS for $10 \mathrm{~min}$ and exposed to X-ray film at $-70^{\circ} \mathrm{C}$. Oligonucleotide radioactive probes used were: HSF1 - 5'-CTG ATG CTG AAC GAC AGT GG-3'; HSP70i - 5' -GCT CGC TCT GCT TCT CTT GT-3'.

\section{Protein extraction and Western blotting}

To prepare tissue extracts, mice were killed by cervical dislocation, testes were immediately dissected, frozen on dry ice and stored at $-70^{\circ} \mathrm{C}$. Testes were homogenized in 5 volumes of buffer consisting of $20 \mathrm{mM}$ Hepes (pH 7.9), 25\% glycerol, 0.42 M NaCl, $1.5 \mathrm{mM} \mathrm{MgCl}_{2}, 0.2 \mathrm{mM}$ EDTA, $1 \mathrm{mM}$ phenylmethylsulfonyl fluoride (PMSF), $0.5 \mathrm{mM}$ DTT, protease inhibitor mixture (Complete ${ }^{\mathrm{TM}}$, Roche), using a Dounce homogenizer, for 
analyses of HSF1 expression. Alternatively, testes were homogenized with buffer consisting of $20 \mathrm{mM}$ Hepes ( $\mathrm{pH} 7.9$ ), $0.2 \mathrm{mM} \mathrm{NaCl}, 0.2 \mathrm{mM}$ EDTA, 1\% NP-40, $1 \mathrm{mM}$ DTT, $1 \mathrm{mM}$ PMSF, 0.25 M sucrose, $50 \mathrm{mM} \mathrm{NaF}$ and protease inhibitor mixture, when other proteins were analyzed. To prepare whole-cell culture extracts, $10^{6}-10^{8}$ confluent cells washed twice with PBS were lyzed by incubation at $4^{\circ} \mathrm{C}$ for $20 \mathrm{~min}$ in $150 \mu \mathrm{l}$ of buffer consisting of $10 \mathrm{mM}$ Tris- $\mathrm{HCl}$ (pH 7.6), $0.14 \mathrm{M} \mathrm{NaCl}, 15 \mathrm{mM} \mathrm{MgCl}_{2}$ and $0.5 \%$ Nonidet $\mathrm{P}-40$. Supernatants were collected after centrifugation at $14000 \times \mathrm{g}$ for $15 \mathrm{~min}$. Proteins $(100 \mu \mathrm{g})$ were separated on $8-15 \%$ SDSPAGE gels and blotted to nitrocellulose filters (BA85 Schleicher \& Schuell). The filters were blocked for $60 \mathrm{~min}$ in $5 \%$ non-fat milk in TTBS (250 mM Tris- $\mathrm{HCl}(\mathrm{pH} \mathrm{7.5),0.1 \%} \mathrm{Tween-20,} 150 \mathrm{mM} \mathrm{NaCl}$ ) and next incubated with primary antibody (listed on Figure 5; Pharmingen) at $4{ }^{\circ} \mathrm{C}$ overnight. The primary antibody was detected by appropriate secondary antibody conjugated with horseradish peroxidase (1:5000, Amersham) and visualized by ECL kit (Pierce). The activities of caspase- $3,-8$ and -9 were assessed in testicular extracts using Caspase Colorimetric Assay Kits (Biovision) according to the manufacturer's protocols. In all, $1 \mathrm{mg}$ of protein extracts was incubated with a caspase substrate for $5 \mathrm{~h}$ at $37^{\circ} \mathrm{C}$ and then the amount of product was measured spectrophotometrically. The testes of 10 animals were pooled for extract preparation and each assay was performed in triplicate.

\section{Histopathology and immunohistochemistry}

Mice were killed by cervical dislocation. Testes were immediately dissected and fixed overnight in $10 \%$ buffered formaldehyde at $4{ }^{\circ} \mathrm{C}$, washed in phosphate-buffered saline (PBS) at $4^{\circ} \mathrm{C}$, dehydrated, paraffinembedded, and stained routinely with hematoxylin and eosin. The following primary antibodies were employed: anti-caspase-3 polyclonal $\mathrm{Ab}$ specific for cleaved p20 subunit ( $1: 30$, overnight at $\left.4^{\circ} \mathrm{C}\right)$ (Biovision) and anti-Hsp70 monoclonal Ab specific for inducible Hsp70i (1:50, overnight $4^{\circ} \mathrm{C}$ ) (clone SPA810; StressGen). Antigen retrieval step in $0.01 \mathrm{M}$ citrate buffer, $\mathrm{pH} 6.0$, was performed before immunohistochemistry procedure with $A B C$ Vectastain kit (Vector), which was performed according to the manufacturer's guidelines. All steps were performed in a humid chamber at room temperature. DAB was used as a chromogen for visualization of immunohistochemical reactions and hematoxylin was used for counterstaining. Apoptotic cells with DNA breaks were detected using TUNEL assay. Briefly, testes were fixed and embedded in paraffin as described above. Sections were cut $5 \mu \mathrm{m}$ thick, deparaffinized and rehydrated on glass slides, and then digested for $15 \mathrm{~min}$ at $37^{\circ} \mathrm{C}$ with $20 \mu \mathrm{g} / \mathrm{ml}$ of proteinase K. Prepared sections were incubated with a mixture composed of terminal transferase (TdT) and labeled nucleotides (fluorescein dUTP) at $37^{\circ} \mathrm{C}$ for $60 \mathrm{~min}$ according to the supplier's protocol (Roche). The samples were washed twice with PBS and treated with DAKO ${ }^{\circledR}$ fluorescent mounting medium. For simultaneous analysis of active caspase- 3 and DNA breaks on the same specimen, immediately after staining for caspase-3 the specimen sections were processed for TUNEL. Counterstaining by hematoxylin and proteinase $\mathrm{K}$ digestion were omitted in this case.

\section{Gene expression profiling by DNA microarrays}

The analysis was performed using the Affymetrix high-density mouse genome 430A array. Total RNA was extracted as described above and purified using the RNeasy kit with on-column digestion with RNase free DNase I (Qiagen). cDNA was synthesized from $8 \mu \mathrm{g}$ of purified total RNA using the Superscript Choice System (Invitrogen) with an oligo-dT primer containing a T7 promoter sequence (Amersham Pharmacia Biotech) and then reverse-transcribed with a T7 RNA polymerase incorporating biotinlabeled nucleotides using the BioArray RNA Transcript Labeling Kit (Enzo Diagnostic). Biotin-labeled cRNA probe samples were purified, fragmented and hybridized at $45^{\circ} \mathrm{C}$ overnight to the $430 \mathrm{~A}$ array (that contains over 22600 probe sets representing transcripts and variants from over 14000 well-characterized mouse genes). The arrays were washed, stained and scanned using a Fluidics Station and microarray scanner, which are components of the Affymetrix GeneChip Instrument System. The data were analyzed using Microarray Suite 5.0 (MAS) software.

\section{Acknowledgements}

We thank Dr. Akira Nakai for a generous gift of the hHSF1 $\triangle$ RD DNA, Dr. William $T$ Garrard for comments and help with preparation of the manuscript, and Mrs. Krystyna Klyszcz for technical assistance. This work was supported by the Ministry of Science and Informatics, Grant KBN 3 P04A 03323.

\section{References}

1. Parvinen M (1982) Regulation of the seminiferous epithelium. Endocr. Rev. 3 : 404-417

2. Print CG and Loveland KL (2000) Germ cell suicide: new insight into apoptosis during spermatogenesis. BioEssays 22: 423-430

3. Hikim AP, Lue Y, Diaz-Romero M, Yen PH, Wang C and Swerdloff RS (2003) Deciphering the pathways of germ cell apoptosis in the testis. J. Steroid Biochem. 85: 175-182

4. Kandeel FR and Swerdloff RS (1988) Role of temperature in regulation of spematogenesis and the use of heating as a method for contraception. Fertil. Steril. 49: 1-23

5. Steinberger $E$ and Dixon WJ (1959) Some observation on the effect of heat on testicular germinal epithelium. Fertil. Steril. 10: 578-595

6. Yin Y, Hawkins KL, Dewolf WC and Morgentaler A (1997) Heat stress causes testicular germ cell apoptosis in adult mice. J. Androl. 18: 159-165

7. Lue Y, Hikim A, Swerdloff RS, Im P, Taing KS, Bui T, Leung A and Wang $C$ (1999) Single exposure to heat induces stage-specific germ cell apoptosis in rats; role of intratesticular testosterone on stage specificity. Endocrinology 140: 1709-1717

8. Beere HM (2004) The stress of dying': the role of heat shock proteins in the regulation of apoptosis. J. Cell Sci. 117: 2641-2651

9. Sreedhar AS and Csermely P (2004) Heat shock proteins in the regulation of apoptosis: new strategies in tumor therapy: a comprehensive review. Pharmacol. Ther. 101: 227-257

10. Gething MJ and Sambrook J (1992) Protein folding in the cell. Nature 355: 33-45

11. Kregel KC (2002) Heat shock proteins: modifying factors in physiological stress responses and acquired thermotolerance. J. Appl. Physiol. 92: 2177-2186

12. Moseley PL (1997) Heat shock proteins and heat adaptation of the whole organism. J. Appl. Physiol. 83: 1413-1417

13. Beere $\mathrm{H}$ and Green DR (2001) Stress management - heat shock protein-70 and the regulation of apoptosis. Trends Cell Biol. 11: 6-10

14. Ravagnan L, Gurbuxani S, Susin SA, Maisse C, Daugas E, Zamzami N, Mak T, Jaattela M, Penninger JM, Garrido C and Kroemer G (2001) Heat-shock protein 70 antagonizes apoptosis-inducing factor. Nat. Cell Biol. 3: 839-843

15. Li WX, Chen CH, Ling CC and Li GC (1996) Apoptosis in heat-induced cell killing: the protective role of hsp-70 and the sensitization effect of the c-myc gene. Radiat. Res. 145: 324-330

16. Tsuchiya D, Hong S, Matsumori Y, Shiina H, Kayama T, Swanson RA, Dillman WH, Liu J, Panter SS and Weinstein PR (2003) Overexpression of rat heat shock protein 70 is associated with reduction of early mitochondrial cytochrome $C$ release and subsequent DNA fragmentation after permanent focal ischemia. J. Cereb. Blood Flow Metab. 23: 718-727 
17. Gotoh T, Terada K, Oyadomari S and Mori M (2004) hsp70-DnaJ chaperone pair prevents nitric oxide- and CHOP-induced apoptosis by inhibiting translocation of Bax to mitochondria. Cell Death Differ. 11: 390-402

18. Komarova EY, Afanasyeva EA, Bulatova MM, Cheetham ME, Margulis BA and Guzhova IV (2004) Downstream caspases are novel targets for the antiapoptotic activity of the molecular chaperone hsp70. Cell Stress Chaperones 9: 265-275

19. Park KC, Kim DS, Choi HO, Kim KH, Chung JH, Eun HC, Lee JS and Seo JS (2000) Overexpression of HSP70 prevents ultraviolet B-induced apoptosis of a human melanoma cell line. Arch. Dermatol Res. 292: 482-487

20. Iordanskiy S, Zhao Y, Dubrovsky L, lordanskaya T, Chen M, Liang D and Bukrinsky M (2004) Heat shock protein 70 protects cells from cell cycle arrest and apoptosis induced by human immunodeficiency virus type 1 viral protein $R$. J. Virol. 78: 9697-9704

21. Allen RL, O'Brien DA, Jones CC, Rockett DL and Eddy EM (1988) Expression of heat shock proteins by isolated mouse spermatogenic cells. Mol. Cell. Biol. 8: 3260-3266

22. Krawczyk Z, Mali P and Parvinen M (1988) Expression of a testis-specific hsp70 gene-related RNA in defined stages of rat seminiferous epithelium. J. Cell Biol. 107: 1317-1323

23. Krawczyk Z, Wisniewski J and Biesiada E (1988) A rat testis-specific hsp70 gene-related transcript is coded by a novel gene from the hsp70 multigene family. Acta Biochim. Pol. 35: 377-385

24. Matsumoto $M$ and Fujimoto $H$ (1990) Cloning of a hsp70-related gene expressed in mouse spermatids. Biochem. Biophys. Res. Commun. 15: 43-49

25. Huang L, Mivechi NF and Moskophodos D (2001) Insights into regulation and function of the major stress-induced hsp70 molecular chaperone in vivo: analysis of mice with targeted gene disruption of the $h s p 70.1$ or $h s p 70.3$ gene. Mol. Cell. Biol. 21: 8575-8591

26. Izu H, Inouye S, Fujimoto M, Shiraishi K, Naito K and Nakai A (2004) Heat shock transcription factor 1 is involved in quality-control mechanisms in male germ cells. Biol. Reprod. 70: 18-24

27. Dix DJ, Allen JW, Collins BW, Mori C, Nakamura N, Poorman-Allen P, Goulding EH and Eddy EM (1996) Targeted gene disruption of Hsp70-2 results in failed meiosis, germ cell apoptosis, and male infertility. Proc. Natl. Acad. Sci. USA 93: 3264-3268

28. Baler R, Dahl G and Voellmy R (1993) Activation of human heat shock genes is accompanied by oligomerization, modification, and rapid translocation of heat shock transcription factor HSF1. Mol. Cell. Biol. 13: 2486-2496

29. Sarge KD, Murphy SP and Morimoto RI (1993) Activation of heat shock gene transcription by heat shock factor 1 involves oligomerization, acquisition of DNA-binding activity, and nuclear localization and can occur in the absence of stress. Mol. Cell. Biol. 13: 1392-1407

30. Pirkkala L, Nykanen P and Sistonen L (2001) Roles of the heat shock transcription factors in regulation of the heat shock response and beyond. FASEB J. 15: 1118-1131

31. Voellmy R (2004) On mechanisms that control heat shock transcription factor activity in metazoan cells. Cell Stress Chaperones 9: 122-133

32. Tessari A, Salata E, Ferlin A, Bartoloni L, Slongo ML and Foresta C (2004) Characterization of HSFY, a novel AZFb gene on the $Y$ chromosome with a possible role in human spermatogenesis. Mol. Hum. Reprod. 10: 253-258

33. Shinka T, Sato Y, Chen G, Naroda T, Kinoshita K, Unemi Y, Tsuji K, Toida K, Iwamoto T and Nakahori Y (2004) Molecular characterization of heat shock-like factor encoded on the human $Y$ chromosome, and implications for male infertility. Biol. Reprod. 71: 297-306

34. Fernandes M, O'Brien T and Lis JT (1994) Structure and regulation of heat shock gene promoters In: The Biology of Heat Shock Proteins and Molecular Chaperones Morimoto RI, Tissieres A, Georgopoulus G (eds) (Cold Spring Harbor: Cold Spring Harbor Press) pp. 375-391

35. Sorger PK and Nelson HC (1989) Trimerization of a yeast transcriptional activator via a coiled-coil motif. Cell 59: 807-813

36. Clos J, Westwood JT, Becker PB, Wilson S, Lambert K and Wu C (1990) Molecular cloning and expression of a hexameric Drosophila heat shock factor subject to negative regulation. Cell 63: 1085-1097

37. Nieto-Sotelo J, Wiederrecht G, Okuda A and Parker CS (1990) The yeast heat shock transcription factor contains a transcriptional activation domain whose activity is repressed under nonshock conditions. Cell 62: 807-817

38. Voellmy R (2005) Dominant-positive and dominant-negative heat shock factors. Methods 35: 199-207
39. Nakai A, Suzuki M and Tanabe M (2000) Arrest of spermatogenesis in mice expressing an active heat shock transcription factor 1. EMBO J. 19: $1545-1554$

40. Widlak W, Benedyk K, Vydra N, Glowala M, Scieglinska D, Malusecka E, Nakai A and Krawczyk Z (2003) Expression of a constitutively active mutant of heat shock factor 1 under the control of testis-specific hst70 gene promoter in transgenic mice induces degeneration of seminiferous epithelium. Acta Biochim. Polon. 50: 535-541

41. Widlak W, Markkula M, Krawczyk Z, Kananen K and Huhtaniemi I (1995) A 252 bp upstream region of the rat spermatocyte-specific hst70 gene is sufficient to promote expression of the hst70-CAT hybrid gene in testis and brain of transgenic mice. Biochim. Biophys. Acta 1264: 191-200

42. Scieglinska D, Widlak W, Konopka W, Poutanen M, Rahman N, Huhtaniemi I and Krawczyk Z (2001) Structure of the $5^{\prime}$ region of the Hst70 gene transcription unit: presence of an intron and multiple transcription initiation sites. Biochem. J. 359: 129-137

43. Scieglinska D, Widlak W, Rusin M, Markkula M and Krawczyk Z (1997) Expression of the testis-specific HSP70-related gene (HST70) gene in somatic non-testicular rat tissues revealed by RT-PCR and transgenic mice analysis. Cell Biol. Int. 21: 813-821

44. Scieglinska D, Vydra N, Krawczyk Z and Widlak W (2004) Location of promoter elements necessary and sufficient to direct testis-specific expression of the Hst70/Hsp70.2 gene. Biochem. J. 379: 739-747

45. Koji T and Hishikawa Y (2003) Germ cell apoptosis and its molecular trigger in mouse testes. Arch. Histol. Cytol. 66: 1-16

46. Rodriguez I, Ody C, Araki K, Garcia I and Vassalli P (1997) An early and massive wave of germinal cell apoptosis is required for the development of functional spermatogenesis. EMBO J. 16: 2262-2270

47. Wang RA, Nakane PK and Koji T (1998) Autonomous cell death of mouse male germ cells during fetal and postnatal period. Biol. Reprod. 58 : 1250-1256

48. Francavilla S, D’Abrizio P, Rucci N, Silvano G, Properzi G, Straface E, Cordeschi G, Necozione S, Gnessi L, Arizzi M and Ulisse S (2000) Fas and Fas ligand expression in fetal and adult human testis with normal or deranged spermatogenesis. J. Clin. Endocrinol. Metab. 85: 2692-2700

49. Koji T (2001) Male germ cell death in mouse testes: possible involvement of Fas and Fas ligand. Med. Electron. Microsc. 34: 213-222

50. Lysiak JJ (2004) The role of tumor necrosis factor-alpha and interleukin- 1 in the mammalian testis and their involvement in testicular torsion and autoimmune orchitis. Reprod. Biol. Endocrinol. 2: 9

51. Perisic O, Xiao H and Lis JT (1989) Stable binding of Drosophila heat shock factor to head-to-head and tail-to-tail repeats of a conserved $5 \mathrm{bp}$ recognition unit. Cell 59: 797-806

52. Trinklein ND, Murray JI, Hartman SJ, Botstein D and Myers RM (2004) The role of heat shock transcription factor 1 in the genome-wide regulation of the mammalian heat shock response. Mol. Biol. Cell 15: 1254-1261

53. Tamai KT, Liu X, Silar P, Sosinowski T and Thiele DJ (1994) Heat shock transcription factor activates yeast metallothionein gene expression in response to heat and glucose starvation via distinct signalling pathways. Mol. Cell. Biol. 14: 8155-8165

54. Dewji NN, Do C and Bayney RM (1995) Transcriptional activation of Alzheimer's beta-amyloid precursor protein gene by stress. Brain Res. Mol. Brain Res. 33: 245-253

55. Singh IS, Viscardi RM, Kalvakolanu I, Calderwood S and Hasday JD (2000) Inhibition of tumor necrosis factor-alpha transcription in macrophages exposed to febrile range temperature. A possible role for heat shock factor-1 as a negative transcriptional regulator. J. Biol. Chem. 275: 9841-9848

56. Cahill CM, Waterman WR, Xie Y, Auron PE and Calderwood SK (1996) Transcriptional repression of the prointerleukin 1-beta gene by heat shock factor 1. J. Biol. Chem. 271: 24874-24879

57. Chen C, Xie Y, Stevenson MA, Auron PE and Calderwood SK (1997) Heat shock factor 1 represses Ras-induced transcriptional activation of the c-fos gene. J. Biol. Chem. 272: 26803-26806

58. Kumagai J, Fukuda J, Kodama $\mathrm{H}$, Murata $\mathrm{M}$, Kawamura $\mathrm{K}$, Itoh $\mathrm{H}$ and Tanaka T (2000) Germ cell-specific heat shock protein 105 binds to p53 in a temperature-sensitive manner in rat testis. Eur. J. Biochem. 267: 3073-3078 
59. Yin Y, Stahl BC, DeWolf WC and Morgentaler A (1998) p53-mediated germ cell quality control in spermatogenesis. Dev. Biol. 204: 165-171

60. Hunt C and Calderwood S (1990) Characterization and sequence of a mouse hsp70 gene and its expression in mouse cell lines. Gene 87: 199-204

61. Suzuki YJ, Mizuno M and Packer L (1994) Signal transduction for nuclear factor-kappa B activation. Proposed location of antioxidant-inhibitable step. J. Immunol. 153: 5008-5015
62. Chomczynski P and Sacchi N (1987) Single-step method of RNA isolation by acid guanidinium thiocyanate-phenol-chloroform extraction. Anal. Biochem. 162: $156-159$

63. Singer-Sam J, Robinson MO, Bellve AR, Simon Ml and Riggs AD (1990) Measurement by quantitative PCR of changes in HPRT, PGK-1, PGK-2, APRT, MTase, and Zfy gene transcripts during mouse spermatogenesis. Nucleic Acids Res. 18: 1255-1259

Supplementary Information accompanies the paper on Cell Death and Diffrentiation website (http://www.nature.com/cdd). 